\title{
UJI TOLERANSI BEBERAPA VARIETAS PADI ( Oryza sativa L. ) TERHADAP NAUNGAN
}

\author{
Alridiwirsah ${ }^{1 *}$, Hamidah $\mathbf{H}^{2}$, Erwin M.H², Muchtar $\mathbf{Y}^{2}$ \\ ${ }^{1 .}$ Fakultas Pertanian Universitas Muhammadiyah Sumatera Utara, Medan- 20238 \\ 2.Program Studi Pasca Sarjana Pertanian Universitas Sumatera Utara Medan- 20155 \\ *Corresponding author: alridiwirsah@gmail.com
}

\begin{abstract}
ABSTRAK
Penelitian ini bertujuan untuk mengetahui uji toleransi beberapa varietas padi (Oriza sativa L) terhadap variasi intensitas penyinaran. Penelitian ini dilaksanakan bulan November 2014 sampai dengan bulan Februari 2015. diKebun Percobaan Pasar Miring, Balai Pengkajian Teknologi Pertanian (BPTP) Sumatera Utara. Jl. Raya-Galang Km 8,2 Lubuk Pakam, Kec. Pagar Merbau, Kab. Deli Serdang, Sumatera Utara. Rancangan yang digunakan dalam penelitian adalah Rancangan Petak Terbagi (RPT) dengan 2 faktor, yaitu: yang pertama faktor Naungan $(N)$ sebagai petak utama dengan 3 taraf yaitu: $N_{0}=$ tanpa naungan $(100 \%$ intensitas penyinaran), $N_{l}=$ dinaungi $25 \%$ (75\% intensitas penyinaran), $N_{2}=$ dinaungi $50 \%$ (50\% intensitas penyinaran). Yang kedua faktor varietas padi $(V)$ sebagai anak petak dengan 5 taraf yaitu : $V_{1}=$ varietas Sidenuk, $V_{2}=$ varietas Ciherang, $V_{3}=$ varietas Inpari 10, $V_{4}=$ varietas Inpari 30 dan $V_{5}=$ varietas Mugibat. Jumlah kombinasi perlakuan 15 kombinasi yang diulang sebayak 3 kali menghasilkan 45 satuan percobaan, jumlah tanaman per plot 40 tanaman dengan 10 tanaman sampel, jumlah tanaman keseluruhan adalah 1800 tanaman dengan jumlah sampel seluruhnya 450 tanaman. Hasil penelitian menunjukkan bahwa perlakuan intensitas penyinaran (naungan) berpengaruh nyata terhadap parameter tinggi tanaman 14 MST, jumlah anakan, jumlah anakan produktif, jumlah gabah berisi per malai, berat gabah kering per plot dan berat gabah kering per Ha. Sedangkan parameter tinggi tanaman 2, 4 dan 6 MST, panjang malai, jumlah gabah per malai, jumlah gabah hampa per malai, berat gabah 1000 biji, kandungan klorofil A, kandungan klorofil B, kandungan klorofil Total tidak berpengaruh yang nyata. Pada perlakuan varietas berpengaruh nyata terhadap parameter tinggi tanaman, jumlah anakan, jumlah anakan produktif, jumlah gabah per malai, jumlah gabah berisi per malai, sedangkan terhadap panjang malai, jumlah gabah hampa per malai, berat gabah 1000 biji, kandungan klorofil A, kandungan klorofil B, kandungan klorofil Total, berat gabah kering per plot, berat gabah kering per $\mathrm{Ha}$, penggunaan varietas tidak memberikan perbedaan yang nyata. Interaksi varietas dan intensitas penyinaran memberi pengaruh yang nyata terhadap jumlah anakan dan jumlah anakan produktif. Sedangkan parameter tinggi tanaman, jumlah gabah per malai, jumlah gabah berisi per malai, panjang malai, jumlah gabah hampa per malai, kandungan klorofil A, kandungan klorofil B, kandungan klorofil Total, berat gabah 1000 butir, berat gabah kering per plot dan berat gabah kering per Ha tidak memberikan perbedaan yang nyata.
\end{abstract}

Kata kunci : Intensitas naungan, Toleransi dan Varietas padi sawah

\section{PENDAHULUAN}

Padi (Oryza sativa L.) merupakan tanaman pangan dari golongan gramineae yang berasal dari dua benua yaitu Asia dan Afrika Barat tropis dan subtropis. Padi
(Oryza sativa L.) merupakan tanaman pangan paling penting di negara-negara berkembang dan merupakan makanan pokok di Indonesia sehingga merupakan komoditas strategis. Pertumbuhan penduduk yang terus bertambah dan 
tersebar di banyak pulau akan dapat menyebabkan ketergantungan terhadap pangan impor dan dapat menyebabkan rentannya ketahanan pangan, yang berdampak terhadap berbagai aspek kehidupan sosial, ekonomi, dan bahkan politik (Perdana, 2007 ; Ramli, 2012).

Dewasa ini alih fungsi lahan sawah irigasi semakin meningkat dari tahun ke tahun yang dipicu oleh adanya kebutuhan untuk berbagai peruntukan yang lebih ekonomis. Berdasarkan data secara nasional, laju konversi lahan sawah irigasi itu telah mencapai 40.000 ha per tahun. Konversi ini sebagian besar terjadi di Jawa dan Sumatera. Bila produksi gabah kering giling (GKG) rata-rata 6 ton/ha/panen dan dalam satu tahun tanam padi dua kali musim tanam, maka produksi GKG nasional menyusut 4.840 .000 ton per tahun (Susanto, 2008).

Lebih lanjut Badan Ketahanan Pangan Nasional menyatakan konversi lahan pertanian di lndonesia pada 2009 luasnya mencapai 110 ribu hektar per tahun yang digunakan untuk kegiatan lain seperti pembangunan perumahan dan alih fungsi sebagai lahan perkebunan (Sutjahjo, 2011).

Tingginya alih fungsi lahan pertanian padi beririgasi, diperlukan suatu kajian alternatif tentang sistem pertanian tumpang sari padi dengan tanaman tahunan. Sehingga produksi padi tetap tersedia dan ketahanan pangan dapat dipertahankan.

Cahaya matahari merupakan sumber energi untuk proses fotosintesis. Serapan cahaya matahari oleh tajuk tanaman merupakan faktor penting yang menentukan fotosintesis untuk menghasilkan asimilat bagi pembentukan bunga, buah dan biji. Cahaya matahari diserap tajuk tanaman secara proporsional dengan total luas lahan yang dinaungi oleh tajuk tanaman. Jumlah, sebaran, dan sudut daun pada suatu tajuk tanaman menentukan serapan dan sebaran cahaya matahari sehingga mempengaruhi fotosintesis dan hasil tanaman (Harsanti, 2011).

Kekurangan cahaya matahari dan air sangat mengganggu proses fotosintesis dan pertumbuhan, meskipun kebutuhan cahaya tergantung tergantung pada jenis tumbuhan. Klorofil dibuat dari hasil-hasil fotosintesis. Tumbuhan yang tidak terkena cahaya tidak dapat membentuk klorofil sehingga daun menjadi pucat. Akan tetapi, jika intensitas cahaya terlalu tinggi, klorofil akan rusak (Lukitasari, 2011).

Padi termasuk tanaman C3 yang dapat memfiksasi karbon atmosferi $\left(\mathrm{CO}_{2}\right)$ menjadi intermediet berkarbon rangkap tiga pada proses fotosintesis. Tanaman C3 dapat mengalami kehilangan air lebih banyak dibandingkan tanaman $\mathrm{C} 4$ seperti jagung dan sorgum. Tanaman C3 memiliki rasio transpirasi yang lebih tinggi dan keadaan stomata selalu terbuka. Tanaman C3 mengalami fotorespirasi yang berdampak pada hasil bersih fotosintesisnya lebih rendah dari tanaman C4. Untuk mengatasi intensitas cahaya yang terlalu tinggi. Pemberian naungan dilakukan pada budidaya tanaman yang umumnya termasuk kelompok C3 maupun dalam fase pembibitan. Pada tanaman kelompok C3, naungan tidak hanya diperlukan pada fase bibit saja, tetapi sepanjang siklus hidup tanaman. Semakin dewasa umur tanaman, intensitas naungan semakin dikurangi. Naungan selain diperlukan untuk mengurangi intensitas cahaya yang sampai ke tanaman pokok, juga dimanfaatkan sebagai salah satu metode pengendalian gulma (Priyatno, 2012).

Intensitas cahaya dan lama penyinaran dalam fotosintesis berpengaruh pada pertumbuhan (vegetatif) dan kegiatan reproduksi (generatif) tumbuhan di daerah tropis, lamanya siang dan malam relatif sama, yaitu 12 jam sedangkan daerah yang memiliki empat musim, lamanya siang hari dapat mencapai $16-20$ jam. Respon tumbuhan terhadap fotoperiodik dapat berupa pembungaan, perkecambahan, dan perkembangan (Pertamawati, 2010). 
Upaya peningkatan produksi padi salah satunya adalah melalui inovasi teknologi varietas unggul baru. Varietas unggul baru selain untuk meningkatkan potensi hasil tinggi juga perlu memperhatikan mutu produk yang dihasilkan mauoun terhadap faktor-faktor pengganggu yang lain. Peningkatan produktifitas usaha tani komoditi tanaman

\section{BAHAN DAN METODE}

Penelitian ini dilaksanakan di Kebun Percobaan Pasar Miring, Balai Pengkajian Teknologi Pertanian (BPTP) Sumatera Utara, Jl. Raya-Galang Km 8,2 Lubuk Pakam, Kec. Pagar Merbau, Kab. Deli Serdang, Sumatera Utara. Penelitian ini dilaksanakan bulan November 2014 sampai dengan bulan Februari 2015. Penelitian yang digunakan adalah 5 varietas padi yaitu Inpari 10, Inpari 30, Sidenuk, Ciherang, Mugibat, paranet 25\% dan 50\%, bambu, pupuk Urea, TSP, KCL, insektisida kenfas 100 EC (Alfa sipermethria $100 \mathrm{~g} / \mathrm{l}$ ), baycarb (BPMC (2Ci-methyl propy) Phenyl Methyl carbamate), herbisida empat enam, AllyPlus (Methyl metsulfuron), moluskisida debestan (besnoid 400 gr), fungisida explore (Difenokonazol $250 \mathrm{~g} / \mathrm{l}$ ). Alat yang di gunakan dalam penelitian ini adalah

\section{HASIL DAN PEMBAHASAN}

\section{Tingkat optimasi intensitas penyinaran terhadap pertumbuhan dan produksi beberapa varietas padi}

Berdasarkan hasil sidik ragam dapat diketahui bahwa perlakuan naungan berpengaruh nyata terhadap parameter tinggi tanaman 14 MST, jumlah anakan, jumlah anakan produktif, berat gabah per plot dan berat gabah per Ha. Sedangkan parameter tinggi tanaman, jumlah anakan, jumlah anakan produktif, jumlah gabah

\begin{abstract}
60\%-65\% ditentukan oleh penggunaan/bibit unggul. Untuk memperkenalkan dan mengembangkan varietas unggul baru maka cara yang paling efektif adalah menguji varietasvarietas unggul baru dan ditanam dilahan petani (Anonim, 2000)
\end{abstract}

cangkul, garu, timbangan analitik, spektrotofometer Uv-Vis, Light intensiometer, gergaji, parang, meteran, alat tulis dan alat lain yang mendukung dalam penelitian ini .

Rancangan yang digunakan dalam penelitian adalah Rancangan Petak Terbagi (Split Plot Design) tiga ulangan, dengan 2 faktor yang teliti, yaitu, faktor pertama, naungan $(\mathrm{N})$ sebagai petak utama dengan 3 taraf yaitu; $\mathrm{N}_{0}=$ tanpa naungan $(100 \%$ intensitas penyinaran), $\mathrm{N}_{1}=$ dinaungi $25 \%$ $\left(75 \%\right.$ intensitas penyinaran), $\mathrm{N}_{2}=$ dinaungi 50\% (50\% intensitas penyinaran), Varietas padi (V) sebagai anak petak dengan 5 varietas, $\mathrm{V}_{1}=$ varietas Sidenuk, $\mathrm{V}_{2}=$ varietas Ciherang, $\mathrm{V}_{3}=$ varietas Inpari $10, \mathrm{~V}_{4}=$ varietas Inpari $30, \mathrm{~V}_{5}=$ varietas Megibat. Luas Plot percobaan $200 \mathrm{~cm}$ x 100, dengan jarak tanam $25 \mathrm{~cm} \mathrm{x}$ $25 \mathrm{~cm}$, jumlah tanaman perplot 40 tanaman,

permalai dan jumlah gabah berisi tidak berpengaruh yang nyata.

Dari hasil penelitian yang telah dilakuan dapat diketahui bahwa pada pengamatan paratameter tinggi tanaman 14 MST menunjukkan hasil yang nyata tinggi tanaman tertinggi terdapat pada $\mathrm{N}_{2}$ pada perlakuan $50 \%$ intensitas penyinaran dengan tinggi tanaman $118,03 \mathrm{~cm}$, dan terendah terdapat pada $\mathrm{N}_{0}$ pada perlakuan $100 \%$ intensitas penyinaran dengan tinggi tanaman 109,39 $\mathrm{cm}$. Pengaruh penaungan menunjukkan pengaruh yang nyata 
terhadap intensitas cahaya yang diterima oleh tanaman padi. Hal ini disebabkan karena tanaman kekurangan cahaya sehingga mengalami etiolasi. Akibatnya tinggi tanaman yang medapat penaungan lebih tinggi dari tanaman kontrol atau yang tidak mendapat penaungan. Menurut (Gatut, 2011) tanaman yang mendapat cekaman naungan cenderung mempunyai jumlah cabang sedikit dan batang yang lebih tinggi dibanding tanaman yang ditanam dalam kondisi tanpa naungan. Perubahan tinggi batang tanaman pada beberapa tanaman akibat naungan sudah tampak mengalami etiolasi pada naungan lebih dari $25 \%$. Etiolasi yang terjadi pada sebagian besar tanaman akibat naungan disebabkan karena adanya produksi dan distribusi auksin yang tinggi, sehingga merangsang pemanjangan sel yang mendorong meningkatnya tinggi tanaman.

Parameter jumlah anakan menunjukkan hasil yang nyata, jumlah anakan tertinggi terdapat pada perlakuan $\mathrm{N}_{0} 100 \%$ intensitas penyinaran dengan jumlah anakan 21,34 dan jumlah anakan terendah terdapat pada perlakuan $\mathrm{N}_{2}$ pada perlakuan $50 \%$ intensitas penyinaran dengan jumlah anakan 12,73. Hasil penelitian menunjukkan bahwa pada parameter jumlah anakan tertinggi terdapat pada perlakuan $\mathrm{N}_{0}$. Berdasarkan hasil tersebut dapat diketahui bahwa pemberian tingkat penaungan yang semakin tinggi dapat menurunkan jumlah anakan tanaman padi. Hal ini dikarenakan hasil fotosintat yang dihasilkan digunakan untuk meningkatkan tinggi tanaman pada tanaman yang mengalami perlakuan penaungan, Sedangkan pada tanaman yang tidak mendapat perlakuan penaungan $\left(\mathrm{N}_{0}\right)$, fotosintat digunakan untuk membentuk anakan. Alnopri (2004) menyatakan pembentukan anakan, pertumbuhan dan produksi tergantung dari dua faktor yaitu faktor keturunan (faktor dalam) diantaranya faktor genetis, lamanya pertumbuhan tanaman, kultivar dan faktor luar meliputi cahaya, suhu, kelembaban, kesuburan tanah, serta pertumbuhan tunas.
Parameter jumlah anakan produktif menunjukkan hasil yang nyata, jumlah anakan tertinggi terdapat pada perlakuan $\mathrm{N}_{0} 100 \%$ intensitas penyinaran dengan jumlah anakan 18,38 dan jumlah anakan terendah terdapat pada perlakuan $\mathrm{N}_{2}$ pada perlakuan $50 \%$ intensitas penyinaran dengan jumlah anakan 9,47. Menurut (Anonim 1983) menyebutkan anakan produktif erat kaitannya dengan jumlah anakan maksimum dimana makin banyak jumlah anakan maksimum maka jumlah anakan produktif nyata lebih banyak.

Parameter berat gabah per plot menunjukkan hasil yang nyata, jumlah anakan tertinggi terdapat pada perlakuan $\mathrm{N}_{0} 100 \%$ intensitas penyinaran dengan berat gabah 1,52 dan berat gabah terendah terdapat pada perlakuan $\mathrm{N}_{2}$ pada perlakuan $50 \%$ intensitas penyinaran dengan jumlah anakan 0,58. Dan parameter berat gabah per Ha yang nyata, berat gabah tertinggi terdapat pada perlakuan $\mathrm{N}_{0} \quad 100 \%$ intensitas penyinaran dengan berat gabah 7,6 dan berat gabah terendah terdapat pada perlakuan $\mathrm{N}_{2}$ pada perlakuan $50 \%$ intensitas penyinaran dengan jumlah anakan 2,94. Hasil penelitian menunjukkan bahwa pada parameter berat gabah per plot dan berat gabah per Ha tertinggi terdapat pada perlakuan N0. Berdasarkan hasil tersebut dapat diketahui bahwa pemberian tingkat penaungan yang semakin tinggi dapat meningkatkan jumlah kehampaan pada tanaman padi. Jumlah intensitas cahaya yang diterima oleh tanaman padi semakin rendah diakibatkan oleh adanya penaungan. Intensitas cahaya yang rendah pada saat pembungaan padi dapat menurunkan karbohidrat yang terbentuk, sehingga menyebabkan meningkatnya gabah hampa. Menurut Abdullah (2004) bahwa agar diperoleh hasil panen yang tinggi harus mempunyai luas daun bendera yang lebar yang berfungsi untuk menangkap sinar matahari yang masuk ke tanaman dan digunakan untuk proses fotosintesis untuk menghasilkan cadangan yang berupa beras. Pada perlakuan $\mathrm{N}_{2}$ pada perlakuan $50 \%$ intensitas penyinaran 
banyak gabah yang hampa, hal ini di karenakan suhu di dalam naungan sangat rendah sehingga mempengaruhi proses pembuahan. Menurut Perdana (2007) temperatur sangat mempengaruhi pengisian biji padi. Temperatur yang rendah dan kelembaban yang tinggi pada waktu pembungaan akan mengganggu proses pembuahan yang mengakibatkan gabah menjadi hampa. Hal ini terjadi akibat tidak membukanya bakal biji. Temperatur yang juga rendah pada waktu bunting dapat menyebabkan rusaknya pollen dan menunda pembukaan tepung sari.

\section{Respon pertumbuhan dan produksi beberapa varietas padi pada kondisi naungan berbeda}

Berdasarkan hasil sidik ragam dapat diketahui bahwa perlakuan varietas berpengaruh nyata terhadap parameter tinggi tanaman, jumlah anakan, jumlah anakan produktif, jumlah gabah permalai, jumlah gabah berisi, sedangkan terhadap panjang malai, jumlah gabah hampa, jumlah klorofil total, berat gabah 1000 butir, berat gabah per plot, berat gabah per Ha, penggunaan varietas tidak memberikan perbedaan yang nyata.

Dari hasil penelitian yang telah dilakuan dapat diketahui bahwa pada pengamatan paratameter tinggi tanaman 14 MST menunjukkan hasil yang nyata. Tinggi tanaman tertinggi pada tanaman padi terdapat pada perlakuan $\mathrm{V}_{1}$ pada varietas sidenuk dengan tinggi tanaman $118,87 \mathrm{~cm}$ dan terendah terdapat pada perlakuan $\mathrm{V}_{5}$ pada varietas mugibat dengan tinggi tanaman $111,26 \mathrm{~cm}$. Hal ini di sebabkan karena pertumbuhan antara varietas yang satu dengan varietas yang lain tidak seragam. Perbedaan tinggi tanaman dari masing-masing varietas di sebabkan karena adanya perbedaan genetik. Perbedaan genetik ini mengakibatkan setiap varietas memiliki ciri khusus yang berbeda satu sama lain. Hal ini sesuai literatur Sitompul dan
Guritno (1995) yang menyatakan bahwa perbedaan susunan genetik merupakan slah satu faktor penyebab keragaman penampilan tanaman. Program genetik yang akan di ekspresikan pada berbagai sifat tanaman yang mencakup bentuk dan fungsi tanaman yang menghasilkan keragaman pertumbuhan tanaman meskipun bahan tanaman yang digunakan berasal dari tanaman yang sama.

Pada pengamatan paratameter jumlah anakan 6 MST menunjukkan hasil yang nyata. Jumlah anakan tertinggi pada tanaman padi terdapat pada perlakuan $\mathrm{V}_{2}$ pada varietas ciherang dengan jumlah anakan 17,75 dan jumlah terendah terdapat pada perlakuan $\mathrm{V}_{4}$ pada varietas inpari 30 dengan jumlah anakan 14. Dan pada pengamatan paratameter jumlah anakan produktif menunjukkan hasil yang nyata. Jumlah anakan tertinggi pada tanaman padi terdapat pada perlakuan $\mathrm{V}_{3}$ pada varietas inpari 10 dengan jumlah anakan 13,33 dan jumlah terendah terdapat pada perlakuan $\mathrm{V}_{4}$ pada varietas inpari 30 dengan jumlah anakan 11,4. Hal ini diakibatkan jumlah anakan dan jumlah anakan produktif pada beberapa varietas berbeda, seperti terdapat pada deskripsi tanaman untuk $\mathrm{V}_{3}$ varietas inpari 10 jumlah anakan yang di hasilkannya lebih banyak di bandingkan pada $\mathrm{V}_{4}$ varietas inpari 30 yang jumlah anakannya sedikit. Hal ini sesuai literatur Kanisius (1990) yang menyatakan jumlah anakan maksimum, dicapai pada umur 50-60 hari setelah tanam. Kemudian anakan yang terbentuk setelah mencapai batas maksimum akan berkurang karena pertumbuhannya yang lemah, bahkan mati, sedangkan anakan yang terbentuk dari masing-masing varietas mempunyai jumlah yang berbeda-beda yaitu antara 19 sampai dengan 54 anakan. Jumlah ankan juga di pengaruhi oleh tingginya temperatur, pada temperatur tinggi, jumlah anakan yang terbentuk lebih banyak.

Pada parameter jumlah gabah permalai tertinggi pada tanaman padi 
terdapat pada perlakuan $\mathrm{V}_{1}$ pada varietas sidenuk dengan jumlah gabah 190,42 dan jumlah gabah terendah terendah terdapat pada perlakuan $\mathrm{V}_{5}$ varietas mugibat dengan jumlah gabah 137,14. Hal ini kemungkinan varietas sidenuk memiliki daya adaptasi kondisi lingkungan yang tinggi dibandingkan dengan varietasvarietas yang lainnya sehingga memiliki jumlah gabah per malai yang banyak. Menurut Qamara (1995) menyatakan bahwa kultivar padi dapat dikelompokkan atas dasar (1) kepekaan terhadap fotoperiodik, (2) jenis pengelolaan airnya, (3) tipe tanaman dan (4) kandungan pati endospermnya, dimana perbedaan variasi sifat akan menyebabkan perbedaan tingkat adaptasi terhadap kondisi lingkungan tertentu. Adapun pembeda sifat-sifat kultivar yang utama antara lain waktu mencapai $50 \%$ muncul malai (cepat atau lambat), jumlah gabah per malai dan panjang batang sampai malai (pendek atau panjang). Selain itu, adanya perbedaan karakter fenotipe yang tampak dari masing-masing varietas disebabkan oleh adanya perbedaan gen yang mengatur karakter tersebut.

Pada parameter jumlah gabah berisi per malai tertinggi pada tanaman padi terdapat pada perlakuan $\mathrm{V}_{1}$ pada varietas sidenuk dengan jumlah gabah berisi 131,16 dan jumlah gabah berisi terendah terdapat pada perlakuan $\mathrm{V}_{5}$ pada varietas mugibat dengan jumlah gabah berisi 100,44 . Hal ini kemungkinan di pengaruhi oleh faktor lingkungan dan genetik.

\section{Hubungan variasi intensitas penyinaran terhadap pertumbuhan dan produksi beberapa varietas padi}

Interaksi varietas dengan intensitas penyinaran meberikan pengaruh yang nyata terhada parameter jumlah anakan dan jumlah anakan produktif dan memberih pengaruh tidak nyata pada tinggi tanaman, panjang malai, jumlah gabah permalai, jumlah gabah berisi, jumlah gabah hampa, jumlah klorofil total, berat 1000 butir, berat gabah per plot dan berat gabah per Ha.

Berdasarkan hasil penelitian tersebut dapat diinterprestasikan bahwa respon masing-masing varietas terhadap intensitas penyinaran yang diberikan tanaman memiliki pola yang sama. Artinya adalah tidak memandang dari varietas apa yang digunakan dalam produksi, pemberian naungan akan berdampak pada penghambatan pertumbuhan dan produksi tanaman.

Hal tersebut terbukti dari tidak munculnya pengaruh interaksi varietas dengan pemberian naungan pada pertumbuhan dan produksi secara umum, kecuali pada parameter jumlah anakan dan jumlah anakan produktif. Hal ini kemungkinan di sebabkan adanya perbedaan ketahanan dari masing-masing varietas terhadap ketahanan perbedaan genetik. Perbedaan genetik ini mengakibatkan setiap varietas memiliki ciri khusus yang berbeda satu sama lain. Hal ini sesuai literatur Sitompul dan Guritno (1995) yang menyatakan bahwa perbedaan susunan genetik merupakan slah satu faktor penyebab keragaman penampilan tanaman. Program genetik yang akan di ekspresikan pada berbagai sifat tanaman yang mencakup bentuk dan fungsi tanaman yang menghasilkan keragaman pertumbuhan tanaman meskipun bahan tanaman yang digunakan berasal dari tanaman yang sama.

\section{SIMPULAN}

Penggunaan varietas berpengaruh nyata terhadap parameter tinggi tanaman, jumlah anakan, jumlah anakan produktif, jumlah gabah permalai dan jumlah gabah berisi. Variasi intensitas penyinaran memberikan pengaruh yang nyata terhadap jumlah anakan, jumlah anakan produktif, berat gabah per plot dan berat gabah per Ha.

Interaksi varietas dan intensitas penyinaran memberi pengaruh yang nyata terhadap jumlah anakan pada perlakuan 
$\mathrm{N}_{0} \mathrm{~V}_{2}(16,33)$ dan jumlah anakan produktif pada perlakuan $\mathrm{N}_{0} \mathrm{~V}_{2}(21,87)$. Sedangkan terhadap parameter yang lain, interaksi kedua perlakuan berpengaruh tidak nyata. Jumlah gabah produksi tertinggi per plot terdapat pada perlakuan N0V3 $(1,58)$ dan terendah terdapat pada perlakuan $\mathrm{N}_{2} \mathrm{~V}_{4}$ $(0,45)$.

\section{SARAN}

Untuk mendapatkan hasil yang lebih baik dengan perlakuan naungan, sebaiknya dilakukan penelitian lanjutan untuk mendapatkan varietas yang benar-benar tahan terhadap intensitas penyinaran.

\section{UCAPAN TERIMA KASIH}

Penulis mengucapkan terima kasih kepada kepala dinas pertanian Kabupaten Labura (Kakanda Fakhruddin Nasution, SP) atas perannya menfasilitasi dan membantu pelaksanaan penelitian ini.

\section{DAFTAR PUSTAKA}

Abdullah, S. 2004. Pengaruh perbedaan jumlah dan umur bibit terhadap pertumbuhan dan hasil padi sawah. Dalam Lamid, Z., et al. (Penyunting). Prosiding Seminar Nasional Penerapan Agroinovasi Mendukung Ketahanan Pangan dan Agribisnis. Sukarami

Alnopri, 2004. Variabilitas genetk dan heritabilitas sifat-sifat pertumbuhan bibit tujuh genotipe kopi robustaarabika, jurnal-jurnal ilmu pertanian indonesia. Volume. 6, nomor 2, 2004.

Andoko, A ., 2002. Budidaya Padi Secara Organik. Cetakan-I. BALITPANG, 1989. Padi. Edisi ke-2. Pusat Penelitian dan Pengembangan Tanaman Pangan. Bogor.Badan Litbang Pertanian. 2007. Pedoman Umum Produksi Benih Sumber Padi. Badan Litbang Pertanian. Departemen Pertanian. 37 hal.
Anonim, 1983. Pedoman Bercocok Tanam Padi Palawija Sayur-sayuran. Departemen Pertanian Satuan Pengendali BIMAS. Jakarta. 2000. TTG-Budidaya Pertanian, Budidaya Padi. Palbapang Bantul

Atman. 2005. Pengaruh sistem tanam bershaf dengan P-starter (shafter) pada padi sawah varietas Batang Piaman. Jurnal Stigma Vol. XIII No. 4, Oktober-Desember 2005. Faperta Universitas Andalas Padang.

Darliah, I. Suprihatin, D. P. Devries, W. Handayati, T. Hermawati dan Sutater,. 2001. Variabilitas Genetik, Heritabilitas, dan Penampilan Fenotipik 18. Klon Mawar Cipanas. Zuriat 3 No.11..

Gatut,W.A.S, T. Sundari, 2011. Perubahan

Karakter Agronomi Aksesi Plasma Nutfah Kedelai di Lingkungan Ternaungi. J. Agron. 39:1-6.

Harsanti, Restiani, 2011 . Potensi Hasil Tanaman Padi Gogo yang Berasosiasi dengan Bakteri Fotosintetik Synechococcus sp. pada Lingkungan yang Terpapar Berbagai Tingkat Penaungan.

Hasrizart, I., 2008. Pertumbuhan dan Produksi Beberapa Varietas Padi Sawah.http://repository.usu.ac.id/h andle/123456789/ 386. Diakses 15 november 2014.

Kaderi H. 2004. Pengamatan Percobaan Bahan Organik Terhadap Tanaman Padi Dirumah Kaca. Balai Penelitian Pertanian Lahan Rawa (Balittra), Banjar Baru

Kanisius, 1990. Budidaya Tanaman Padi. Penerbit Kanisius. Yogyakarta.

Kisman, N. Khumaida, Trikoesoemaningtyas, Sobir dan D. Sopandie. 2008. Pola Pewarisan adaptasi Kedelai (Glycine max L.Merril) Terhadap Cekaman Naungan Berdasarkan Karakter Morfo-Fisiologi Daun. IPB. Bogor. 
Lakitan, 1993. Dasar-dasar Fisiologi Tumbuhan. PT Raja Grafindo Persada.Jakarta

Lukitasari, Marheny. 2011. Pengaruh Intensitas Cahaya Matahari Terhadappertumbuhan Tanaman Kedelai (Glycine max). http ://http://www.academia.edu/ 6301530/pengaruh intensitas cahaya matahari terhadap_pertumbuhan _tanaman_ kedelai_glycine_max. diakses tanggal 04 november 2014

Masdar. 2007. Interaksi Jarak Tanam dan Jumlah Bibit per Titik Tanam pada Sistem Intensifikasi Padi terhadap Pertumbuhan Vegetatif Tanaman. Jurnal Akta Agrosia Edisi Khusus.

Nurhayati AP, Lontoh, Koswara J. 1999. Pengaruh Intensitas dan Saat Pemberian Naungan terhadap Produksi Ubi Jalar (Ipomoea batatas (L.) Lamp.). Bul. Agr 16:28-38

Perdana, A. S. 2007. Budidaya Padi Gogo. Mahasiswa Swadaya Penyuluhan dan Komunikasi Pertanian UGM. Yogyakarta.

Pertamawati, 2010. Pengaruh Fotosintesis Terhadap Pertumbuhan Tanaman Kentang (Solanum tuberosum L.) Dalam Lingkungan Fotoautotrof Secara Invitro. Pusat TFM - BPP Teknologi. Jakarta

Priyatno, T.P., 2012. Pengembangan Padi C4 Strategi Inovasi Adaptif Menghadapi Pemanasan Global. Balai Besar Penelitian dan Pengembangan Bioteknologi dan Sumberdaya Genetik Pertanian.

Qamara, W, . 1995. Pengantar Produksi Benih. Raja Grafindo Perssada. Jakarta

Ramli, 2012. Pengaruh Umur Transplanting Terhadap Pertumbuhan Vegetatif Berbagai Varietas Padi. Jurnal Agrisistem. Juni 2012, Vol. 8 No. 1 ISSN 1858-4330. Sekolah Tinggi Penyuluhan Pertanian. Gowa.
Siregar H, 1987. Budidaya Tanaman Padi Di Indonesia. PT Sastra Hudaya. Jakarta - pusat.

Sitompul, B dan B. Guritno. 1995. Analisis Pertumbuhan Tanaman. Gadjah Mada University Press. Yogyakarta.

Soeverda, N, 2009. Evaluasi dan Seleksi Varietas Beberapa Tanaman Terhadap Naungan dan Intensitas Cahaya Rendah. Zuriat. Vol.19 No.2. 
Tabel . Rangkuman Hasil Uji Beda Rata-Rata Uji Toleransi Beberapa Varietas Padi (Oryza sativa L) Terhadap Variasi Intensitas Penyinaran

\begin{tabular}{|c|c|c|c|c|c|c|c|c|c|c|c|}
\hline \multirow[b]{2}{*}{ perlakuan } & \multicolumn{11}{|c|}{ Pengamatan } \\
\hline & $\begin{array}{c}\text { Tinggi } \\
\text { tanaman } 14 \\
\text { mst }\end{array}$ & Jlh anakan & $\begin{array}{l}\text { Jumlah } \\
\text { anakan } \\
\text { produktif }\end{array}$ & $\begin{array}{l}\text { Pjg malai } \\
\quad(\mathrm{cm})\end{array}$ & $\begin{array}{l}\text { Jlh gabah } \\
\text { per malai }\end{array}$ & $\begin{array}{c}\text { Jlh gabah } \\
\text { berisi per } \\
\text { malai }\end{array}$ & $\begin{array}{l}\text { Jlh gabah } \\
\text { hampa } \\
\text { per malai }\end{array}$ & $\begin{array}{c}\text { Berat } \\
\text { gabah } \\
1000 \text { biji }\end{array}$ & $\begin{array}{c}\text { Kadar } \\
\text { klorofil } \\
\text { total }\end{array}$ & $\begin{array}{c}\text { Berat } \\
\text { gabah } \\
\text { kering } \\
\text { per plot }\end{array}$ & $\begin{array}{l}\text { Berat } \\
\text { gabh } \\
\text { kering } \\
\text { per Ha }\end{array}$ \\
\hline \multicolumn{12}{|c|}{ Intent penyinaran $(\mathrm{N})$} \\
\hline $\mathrm{N}_{0}$ & $109,39 \mathrm{c}$ & $21,34 \mathrm{a}$ & $18,38 \mathrm{a}$ & 24,67 & 161,29 & $127.19 \mathrm{a}$ & 35,37 & 33,22 & 5,36 & $1,52 \mathrm{a}$ & $7,60 \mathrm{a}$ \\
\hline $\mathrm{N}_{1}$ & $116,47 \mathrm{~b}$ & $13,87 b$ & $9,79 \mathrm{~b}$ & 24,04 & 151,4 & $108,92 b$ & 41,86 & 34,51 & 5,74 & $0,71 \mathrm{~b}$ & $3,56 \mathrm{~b}$ \\
\hline $\mathrm{N}_{2}$ & $118,03 \mathrm{a}$ & $12,73 c$ & $9,47 \mathrm{c}$ & 24,34 & 162,27 & $102,92 \mathrm{c}$ & 48,22 & 32,90 & 6,47 & $0,58 \mathrm{c}$ & $2,94 \mathrm{c}$ \\
\hline \multicolumn{12}{|l|}{ Varietas (V) } \\
\hline $\mathrm{V}_{1}$ & $118,87 \mathrm{a}$ & $16,04 b$ & $12,78 \mathrm{c}$ & 24,48 & $190,42 \mathrm{a}$ & $131,16 \mathrm{a}$ & 39,82 & 39,91 & 3,34 & 0,99 & 4,95 \\
\hline $\mathrm{V}_{2}$ & $116,52 \mathrm{~b}$ & $17,75 \mathrm{a}$ & $13,11 \mathrm{a}$ & 24,21 & $160,62 b$ & $123,81 b$ & 42,34 & 32,64 & 3,40 & 0,96 & 4,8 \\
\hline $\mathrm{V}_{3}$ & $112,97 \mathrm{c}$ & $17,12 \mathrm{a}$ & $13,33 \mathrm{a}$ & 24,57 & $150,02 \mathrm{c}$ & $102,65 \mathrm{~cd}$ & 45,1 & 34,38 & 3,40 & 0,99 & 4,97 \\
\hline $\mathrm{V}_{4}$ & $113,56 \mathrm{c}$ & $14 \mathrm{~d}$ & $11,4 \mathrm{e}$ & 24,71 & $153,4 \mathrm{bc}$ & $107 \mathrm{c}$ & 44,34 & 33,61 & 3,28 & 0,92 & 4,63 \\
\hline $\mathrm{V}_{5}$ & $111,26 \mathrm{~d}$ & $14,98 \mathrm{c}$ & $12,1 \mathrm{~d}$ & 23,81 & $137,14 d$ & $100,4 d$ & 37,5 & 33,18 & 3,35 & 0,83 & 4,16 \\
\hline \multicolumn{12}{|l|}{$\mathrm{NxV}$} \\
\hline $\mathrm{N}_{0} \mathrm{~V}_{1}$ & 112,53 & 20,47 & 17,67 & 24,67 & 182,17 & 148,23 & 33,93 & 33,95 & 3,15 & 1,56 & 7,82 \\
\hline $\mathrm{N}_{0} \mathrm{~V}_{2}$ & 109,77 & 21,87 & 18,57 & 24,69 & 155,60 & 134,77 & 36,20 & 32,76 & 3,45 & 1,54 & 7,70 \\
\hline $\mathrm{N}_{0} \mathrm{~V}_{3}$ & 108,77 & 21,83 & 18,93 & 24,61 & 157,17 & 116,50 & 34,10 & 34,22 & 3,49 & 1,58 & 7,88 \\
\hline $\mathrm{N}_{0} \mathrm{~V}_{4}$ & 108,27 & 20,70 & 17,83 & 24,49 & 156,33 & 121,57 & 32,67 & 33,17 & 3,16 & 1,55 & 7,75 \\
\hline $\mathrm{N}_{0} \mathrm{~V}_{5}$ & 107,90 & 21,83 & 18,90 & 24,90 & 155,20 & 114,90 & 39,97 & 32,03 & 3,26 & 1,38 & 6,88 \\
\hline $\mathrm{N}_{1} \mathrm{~V}_{1}$ & 122,70 & 13,63 & 10,43 & 24,00 & 153,20 & 114,20 & 37,53 & 33,84 & 3,43 & 0,70 & 3,50 \\
\hline $\mathrm{N}_{1} \mathrm{~V}_{2}$ & 118,77 & 16,50 & 10,70 & 23,54 & 161,20 & 115.57 & 47,17 & 33,56 & 3,31 & 0,65 & 3,27 \\
\hline $\mathrm{N}_{1} \mathrm{~V}_{3}$ & 115,17 & 15,53 & 10,73 & 24,63 & 156,63 & 109,07 & 47,53 & 35,65 & 3,46 & 0,83 & 4,13 \\
\hline $\mathrm{N}_{1} \mathrm{~V}_{4}$ & 115,17 & 11,90 & 8,67 & 24,76 & 155,40 & 107,53 & 44,80 & 34,56 & 3,25 & 0,79 & 3,93 \\
\hline $\mathrm{N}_{1} \mathrm{~V}_{5}$ & 110,57 & 11,80 & 8,40 & 23,55 & 130,57 & 98,27 & 32,30 & 34,98 & 3,45 & 0,60 & 3,00 \\
\hline $\mathrm{N}_{2} \mathrm{~V}_{1}$ & 121,37 & 14,03 & 10,27 & 24,79 & 235,90 & 131,07 & 48,00 & 33,96 & 3,46 & 0,71 & 3,53 \\
\hline $\mathrm{N}_{2} \mathrm{~V}_{2}$ & 121,03 & 14,90 & 10,07 & 24,40 & 165,07 & 121,10 & 43,67 & 31,61 & 3,45 & 0,69 & 3,43 \\
\hline $\mathrm{N}_{2} \mathrm{~V}_{3}$ & 115,23 & 14,00 & 10,33 & 24,48 & 136,27 & 82,40 & 53,67 & 33,29 & 3,25 & 0,58 & 2,90 \\
\hline $\mathrm{N}_{2} \mathrm{~V}_{4}$ & 117,23 & 9,40 & 7,70 & 24,89 & 148,47 & 91,90 & 55,57 & 33,12 & 3,45 & 0,45 & 2,23 \\
\hline $\mathrm{N}_{2} \mathrm{~V}_{5}$ & 115,30 & 11,33 & 9,00 & 23,16 & 125,67 & 88,17 & 40,23 & 32,54 & 3,36 & 0,52 & 2,60 \\
\hline KK (a) \% & 2,81 & 5,93 & 13,89 & 5,7 & 15,38 & 14,66 & 28,5 & 5,4 & 6,49 & 24,8 & 24,8 \\
\hline $\mathrm{Kk}$ (b) $\%$ & 2,16 & 7,19 & 5,50 & 3,8 & 18,99 & 11,85 & 17,8 & 4,3 & 5,12 & 13,4 & 13,4 \\
\hline
\end{tabular}

Keterangan : Angka yang diikuti huruf yang tidak sama pada kolom dan baris yang sama berbeda nyata menurut Uji DMRT 5 \% 
Vol.2, No.2. Agustus 2015. (12) : 93- 101 